Tropical Journal of Pharmaceutical Research, February 2009; 8 (1): 71-77

(C) Pharmacotherapy Group,

Faculty of Pharmacy, University of Benin

Benin City, 300001 Nigeria.

All rights reserved.

Research Article

Available online at http://www.tjpr.org

\title{
Toothpaste formulation efficacy in reducing oral flora
}

\section{J Okpalugo*, K Ibrahim, US Inyang}

Department of Microbiology and Biotechnology. National Institute for Pharmaceutical Research and Development (NIPRD), P.M.B. 21, Idu Industrial Area, Abuja, Nigeria

\begin{abstract}
Purpose: To assess the microbial quality as well as the effectiveness of seven brands of toothpaste marketed in Abuja, Nigeria's capital city, for reducing oral bacterial flora.

Methods: Seven brands of toothpaste were randomly purchased from the open market in Abuja. Two brands contained triclosan + sodium fluoride as antibacterial, four contained sodium fluoride only and one was herbal. Each of the toothpaste products was assessed in duplicate for microbial safety based on growth on nutrient agar and broth. Also, eight volunteers were enrolled who used a toothpaste brand 12hourly on three consecutive occasions as the only source of oral hygiene, and then switched over to another brand. Mouth swaps and saliva before and after brushing was taken, plated by the pour plate technique, incubated at $37^{\circ} \mathrm{C}$ and then counted on nutrient agar after $24 \mathrm{~h}$. Percentage bacterial reduction was calculated from the difference in bacterial counts before and after brushing.

Results: All the toothpaste brands were sterile. $71 \%$ of the toothpaste brands were found to significantly $(p=0.068)$ increase saliva bacteria counts. No brand of toothpaste removed teeth bacteria by up to $50 \%$. On average, the two triclosan-containing toothpaste brands exerted a greater reduction in mouth bacteria than non-triclosan toothpaste brands. This was followed by the herbal toothpaste. The toothpaste brands that contained only fluoride were the least effective in reducing mouth bacteria.

Conclusion: The results from our study indicate the need for further research into the possible value of toothpaste for reducing oral bacterial flora.
\end{abstract}

Keywords: Tooth bacteria, Oral bacteria, Triclosan, Toothpaste, Fluoride, Natural toothpaste 


\section{INTRODUCTION}

The purpose of oral hygiene using toothpaste is to reduce oral bacterial flora. Mouth bacteria have been linked to plaque, tooth decay and toothache. Plaque ${ }^{1}$ (a layer that forms on the surface of a tooth, principally at its neck; composed of bacteria in an organic matrix) has been linked to gingivitis, periodontal disease, or dental carries ${ }^{2}$. Previous studies have shown that dental plaque can be controlled by physical removal of plaque, use of antimicrobial toothpastes and mouthwashes 3,4 . There are diverse types of mouth bacteria. Some are useful, others are hurtful: Neisseria, Staphylococcus, S. pneumoniae, Porphyromonas gingivalis, Diphtheriod, Fusobacteria and Haemophilus ${ }^{5}$.

Toothpaste is classified as drugs not cosmetics. Because drugs should contain an ingredient to achieve the effect the consumer desires, it is important to determine if different brands of toothpastes contain effective antibacterial ingredients such as Triclosan 2, 4, 4' trichloro-2'-hydroxydiphenyl ether which is a broad-spectrum antibacterial agent, and fluoride, to effectively reduce mouth bacteria and contribute to dental health ${ }^{6}$.

The main purpose of toothpaste is to reduce oral bacterial flora and deliver fluoride to the teeth. This is because fluoride has been proven to protect teeth against attack from bacteria and can be found naturally in many everyday things including food and drinking water. Toothpaste that efficiently reduces oral bacterial flora should contribute to dental health. Triclosan is usually used in gum. It is a constituent used to avert gum disease because of its antibacterial properties. The active ingredient sodium fluoride is also known to have antibacterial properties ${ }^{7}$.

Natural toothpastes are those without triclosan or fluoride. They usually contain natural ingredients such as special mineral salts e.g. Sodium Fluoride and Sodium Chloride, and plant extracts like lemon, eucalyptus, rosemary, chamomile, sage and myrrh.
Studies have advised that consumers avoid all products that make "antibacterial claims" (unless they are using herbs to accomplish it) but there final decision is for the consumer to make.

Because the information gained from this study could help dentists and consumers in Nigeria to choose the type of toothpaste that would reduce oral bacteria best, thus improving dental health ${ }^{8}$ an evaluation of the effectiveness of toothpaste brands marketed in Abuja, Nigeria's capital city to reduce oral bacteria cannot be overemphasized.

\section{MATERIALS AND METHODS}

\section{Sampling}

Seven brands of toothpaste were randomly purchased from the open market in Abuja. Two of the toothpaste brands contained triclosan T004 and T006, four contained fluoride T001, T002, T005 and T007 and one was herbal T003. The labeled compositions of the toothpaste brands are indicated in Table 1. Each toothpaste brand was assessed in duplicate for microbial status, using growth on nutrient agar and broth. 8 volunteers were recruited into the study. Each volunteer used toothpaste 12-hourly on three consecutive occasions as the only means of oral hygiene, and then switched to another brand. Mouth swaps and saliva before and after brushing were taken, washed in $10 \mathrm{ml}$ of sterile saline, and counted on nutrient agar after $24 \mathrm{~h}$ and percent reduction in bacterial content calculated. Prior to the test, volunteers were observed and instructed on how to brush with the toothpastes. Exclusion criteria: volunteers with any visible tooth or mouth infection or disease, were diabetic, pregnant/lactating, on antibacterial, or suffering from transmissible diseases. The age of volunteers ranged from 18-60 years with a mean age of 39 years. Six volunteers $(75 \%)$ were female. Sterile carrying cases $(10 \mathrm{ml}$ opaque plastic containers with twist covers) were used in collecting oral bacteria which were labeled with the volunteer's name. The samples were 
analyzed within $24 \mathrm{~h}$ after receipt at the laboratory. The time between brushing and swabbing; toothbrush/cup type, amount of toothpaste used, brushing method, brushing time, and the bacterial count method used were kept constant throughout the study ${ }^{9}$. Powders for preparing microbial media were rehydrated according to the manufacturer's instructions.

\section{Isolation of microorganisms}

Ten-fold serial dilutions of $0.5 \mathrm{mg}$ of toothpaste were made up to $10^{-3}$ with sterile water. Samples were plated in duplicate using the pour plate technique. The diluted sample $(0.5 \mathrm{ml})$ was added to $19.5 \mathrm{ml}$ of nutrient agar (Fluka Biochemika, Spain), Sabouraud dextrose agar (Merck, Germany) and plate count agar (Oxoid, UK). Plates were incubated upside down in an incubator at $37^{\circ} \mathrm{C}$ for $24-48 \mathrm{~h}$.

Appropriate positive controls (agar plates indicating the presence of $E$. coli, Pseudomonas aeruginosa, Staphylococcus aureus, Klebsiella pneumoniae, Enterococcus faecalis, and Salmonella typhi) and negative controls (agar plates containing only nutrient agar, sabouraud dextrose agar, plate count agar, sterile water and normal saline) were plated in duplicate to determine the sources of contamination, if any, in the work and as a useful guide in identification of microbial colonies.

\section{Oral bacterial flora count}

Eight volunteers were recruited into the study by word of mouth. Each volunteer used toothpaste 12-hourly on three consecutive occasions as only source of oral hygiene, before switching over to another brand. Mouth swaps (rolled thrice over different sections of the teeth and tongue) and saliva before and after brushing was taken. The swabs were washed in $10 \mathrm{ml}$ of sterile normal saline. Saliva $(0.5 \mathrm{ml})$ was diluted with $9.5 \mathrm{ml}$ of sterile water. Ten-fold serial dilutions of both washed swab and saliva were made up to $10^{-6}$ with sterile normal saline and plated in duplicate using the pour plate technique. The diluted sample $(0.5 \mathrm{ml})$ was delivered by pipette into $19.5 \mathrm{ml}$ of nutrient agar (Fluka Biochemika, Spain). Plates were incubated upside down in an incubator at $37^{\circ} \mathrm{C}$ for $24 \mathrm{~h}$ and oral bacterial flora counted after $24 \mathrm{~h}$. Percent bacterial reduction was calculated from the difference in bacterial counts before and after brushing.

Appropriate positive controls (agar plates containing some mouth flora: Staphylococcus aureus and Streptococcus pneumoniae) cultured using the pour plate technique and negative controls (agar plates containing only nutrient agar, sabouraud dextrose agar, plate count agar, sterile water and normal saline) were plated in duplicate to determine the sources of contamination, if any, in the work and as a useful guide in identification of microbial colonies isolated from the mouth swab.

\section{Statistical analysis}

The data obtained were analyzed using SPSS (Statistical Package for Social Sciences) 10.0 for Windows, an installable software that enables assessment of data using several statistical functions. Chi Test was also used to test for independence.

\section{RESULTS}

Analysis for microbial load of the toothpastes shows that they were all sterile as no bacterial or fungal isolates were identified and this shows that the microbial quality of toothpaste formulations marketed in the Abuja open markets, has met the drug standard which excludes the presence of the index, indicator or pathogenic organism in drugs to be consumed by the populace. For the reduction in oral bacterial flora counts by toothpaste brands, see (Tables 1 and 2).

\section{DISCUSSION}

Tables 1 and 2 show reduction in oral (teeth and saliva) bacterial flora counts for the toothpaste brands. Some toothpastes (71\%) were found to significantly increase 
Okpalugo et al

Table 1: Effectiveness of toothpastes in removing teeth bacteria

\begin{tabular}{llllll}
\hline $\begin{array}{l}\text { Toothpaste } \\
\text { brand }\end{array}$ & $\begin{array}{l}\text { Average } \\
\text { mouth } \\
\text { bacteria count } \\
\text { before } \\
\text { brushing } \\
(\text { CFU/ml) }\end{array}$ & $\begin{array}{l}\text { Average } \\
\text { mouth } \\
\text { bacteria count } \\
\text { after brushing } \\
\text { in (CFU/ml) }\end{array}$ & $\begin{array}{l}\text { Reduction in } \begin{array}{l}\text { mouth } \\
\text { bacterial } \\
\text { count } \\
(\text { CFU/ml) }\end{array} \\
\text { in Reduction } \\
\text { mouth }\end{array}$ & $\begin{array}{l}\text { Rank } \\
\text { bacteria count }\end{array}$ & \\
\hline T001 & 160,000 & 108,800 & 51,200 & 32 & $4^{\text {th }}$ \\
T002 & 200,000 & 120,000 & 60,000 & 30 & $5^{\text {th }}$ \\
T003 & 118,000 & 73,160 & 44,840 & 38 & $3^{\text {rd }}$ \\
T004 & 400,000 & 236,000 & 164,000 & 41 & $2^{\text {nd }}$ \\
T005 & 230,000 & 165,600 & 64,400 & 28 & $6^{\text {th }}$ \\
T006 & 260,000 & 132,600 & 127,400 & 49 & $1^{\text {st }}$ \\
T007 & 120,000 & 92,400 & 27,600 & 23 & $7^{\text {th }}$ \\
\hline
\end{tabular}

Table 2: Effectiveness of toothpastes in removing saliva bacteria

\begin{tabular}{|c|c|c|c|c|c|c|}
\hline $\begin{array}{l}\text { Toothpaste } \\
\text { brand }\end{array}$ & $\begin{array}{l}\text { Average } \\
\text { saliva } \\
\text { bacteria } \\
\text { count } \\
\text { before } \\
\text { brushing in } \\
(\mathrm{CFU} / \mathrm{ml})\end{array}$ & $\begin{array}{l}\text { Average } \\
\text { saliva } \\
\text { bacteria } \\
\text { count after } \\
\text { brushing in } \\
(\mathrm{CFU} / \mathrm{ml})\end{array}$ & $\begin{array}{l}\text { Reduction } \\
\text { in saliva } \\
\text { bacterial } \\
\text { count } \\
(\mathrm{CFU} / \mathrm{ml})\end{array}$ & $\begin{array}{l}\text { \% } \\
\text { Reduction } \\
\text { in saliva } \\
\text { bacteria } \\
\text { count }\end{array}$ & $\begin{array}{l}\text { Increase in } \\
\text { saliva } \\
\text { bacterial } \\
\text { count } \\
(\mathrm{CFU} / \mathrm{ml})\end{array}$ & $\begin{array}{l}\% \\
\text { Increase } \\
\text { in saliva } \\
\text { bacteria } \\
\text { count }\end{array}$ \\
\hline T001 & 300,000 & 405,000 & $\overline{0}$ & 0 & 105,000 & 35 \\
\hline T002 & 360,000 & 435,000 & 0 & 0 & 75,000 & 21 \\
\hline T003 & 500,000 & 480,000 & 20,000 & 4 & 0 & 0 \\
\hline T004 & 700,000 & 800,000 & 0 & 0 & 100,000 & 14 \\
\hline T005 & 800,200 & 900,500 & 0 & 0 & 100,300 & 13 \\
\hline T006 & 540,800 & 508,325 & 32,475 & 6 & 0 & 0 \\
\hline T007 & 400,000 & 520,000 & 0 & 0 & 120,000 & 30 \\
\hline
\end{tabular}

saliva bacterial counts (Table 2). The reason for this is not clear but may be due to the ingredients (sodium saccharin and other sweeteners) in the toothpaste 10,11. However, further researches on this have to be done. No brand of toothpaste removed teeth bacteria by up to $50 \%$ (Tables 1 and 2). The result would appear to call for further research into the possible value of toothpaste reducing oral bacterial flora.

On the average, toothpastes containing two antibacterials sodium fluoride + triclosan had a 20\% T006 $\left(1^{\text {st }}\right)$ and 7\% T004 $\left(2^{\text {nd }}\right)$ more reduction in oral bacterial flora than non- triclosan containing toothpastes. (Table 1 and 2) This result shows that toothpastes that contain triclosan as an antibacterial in addition to sodium fluoride are moderately (7\%-20\%) more effective than toothpastes containing only sodium fluoride as an active antibacterial ingredient and this is in harmony with works done in other dental hygiene studies ${ }^{12,13}$. Though this is statistically significant $(p=0.032)$, claims have been made on the safety profile of triclosan ${ }^{14}$.

T003 had a $16 \%\left(3^{\text {rd }}\right)$ more reduction than the sodium fluoride only toothpastes and this is statistically significant $(p=0.009)$. This may be 
Table 3: Details about the toothpastes used in the study

\begin{tabular}{|c|c|c|}
\hline $\begin{array}{l}\text { Toothpaste } \\
\text { Code }\end{array}$ & $\begin{array}{l}\text { Toothpaste } \\
\text { Brand Name }\end{array}$ & Composition of the Toothpaste \\
\hline T001 & $\begin{array}{l}\text { Macleans }^{\Theta} \\
\text { Complete Care }\end{array}$ & $\begin{array}{l}\text { Active Ingredient: Sodium Fluoride } 0.306 \% \text { w/w. } \\
\text { Aqua, Hydrated Silica, Sorbitol, Glycerin, PEG-6, Sodium } \\
\text { Lauryl Sulphate, Flavor, Xanthan gum, Sodium Saccharin, } \\
\mathrm{Cl} 73360, \mathrm{Cl} 74160 \text {. }\end{array}$ \\
\hline T002 & $\begin{array}{l}\text { Macleans }{ }^{\circledR} \\
\text { Fresh mint }\end{array}$ & $\begin{array}{l}\text { Active Ingredient: Sodium Fluoride } 0.306 \% \text { w/w. } \\
\text { Aqua, Hydrated Silica, Sorbitol, Glycerin, PEG-6, Sodium } \\
\text { Lauryl Sulphate, Flavor, Titanium Dioxide, Xanthan gum, } \\
\text { Sodium Saccharin. }\end{array}$ \\
\hline T003 & $\begin{array}{l}\text { Dabur } \\
\text { Gel }^{\Theta}\end{array}$ & $\begin{array}{l}\text { Active Ingredients: Natural Lemon Extract, Flavor } \\
\text { containing Natural Blend of Mint, Eucalyptus, Rosemary, } \\
\text { Chamomile, Sage, Myrrh \& other Natural Oils. } \\
\text { Sorbitol, Silica, Treated Water, Poly Ethylene Glycol 1500, } \\
\text { Sodium Lauryl Sulphate, } \\
\text { Carboxy Methyl Cellulose, Sodium Saccharin, Tri Sodium } \\
\text { Ortho Phosphate, Citric Acid FD \& C Blue \# 1, FD \& C } \\
\text { Yellow \# 5. }\end{array}$ \\
\hline T004 & $\begin{array}{l}\text { Crest } 5 \\
\text { Complete Care }^{\circledR}\end{array}$ & $\begin{array}{l}\text { Active Ingredient: Sodium Fluoride } 0.321 \%(1450 \mathrm{ppm} \text { F) } \\
\text { Aqua, Sorbitol, Hydrated Silica, PEG-6, Sodium Lauryl } \\
\text { Sulfate, Tetrapotassium Pyrophosphate, Disodium } \\
\text { Pyrophosphate, Tetrasodium Pyrophosphate, Aroma, } \\
\text { Cellulose Gum, Xanthan Gum, Carbomer, Sodium } \\
\text { Saccharin, Triclosan, Glycerin, Limonene, Cl } 74160 \text {, Cl } \\
74260, \mathrm{Cl} 77891 .\end{array}$ \\
\hline T005 & Flourish Gel ${ }^{\circledR}$ & $\begin{array}{l}\text { Active Ingredients: } 0.76 \% \text { Sodium Mono Fluoro } \\
\text { phosphate. Sorbitol, Water, Silica, PEG, Sodium Lauryl } \\
\text { Sulphate, Flavor, Magnesium Sulphate, Cellulose Gum, } \\
\text { Sodium Saccharin, Trisodium Phosphate, Methyl } \\
\text { Paraben, Menthol, FD \& C Red No 40, D \& C Red No. } 33 \text {. }\end{array}$ \\
\hline T006 & $\begin{array}{l}\text { Colgate Triple } \\
\text { Action }^{\circledR}\end{array}$ & $\begin{array}{l}\text { Active Ingredients: Sodium Monofluorophosphate } 1.1 \% \\
\text { (1450 ppm F), Triclosan 0.1\%. Aqua, Sorbitol, Calcium } \\
\text { Carbonate, Hydrated Silica, Glycerin, PEG-12, Sodium } \\
\text { Lauryl Sulfate, Sodium Monofluorophosphate, Flavor, } \\
\text { Cellulose Gum, Carrageenan (Chondrus Crispus), } \\
\text { Xanthan Gum, Sodium Silicate, Sodium Saccharin, } \\
\text { Triclosan, Sodium Bicarbonate, Methylparaben, } \\
\text { Butylparaben, Ethylparaben, Propylparaben, Cl } 74260 \text {, Cl } \\
74160 .\end{array}$ \\
\hline T007 & $\begin{array}{l}\text { Close up }^{\circledR} \\
\text { (Fresh Red) }\end{array}$ & $\begin{array}{l}\text { Active Ingredient: Sodium Fluoride }(0.32 \%) \\
\text { Sorbitol, Hydrated Silica, water, SLS, Peg-32, Flavor, } \\
\text { Cellulose Gum, Sodium Saccharin, Trisodium Phosphate, } \\
\text { Vitamin-E-Acetate, Cl } 16035, \text { Cl } 17200 .\end{array}$ \\
\hline
\end{tabular}


are using herbs to accomplish it) but there final decision is for the consumer to make. Consumers should also bear in mind that unless these natural toothpaste have been proven through research to accomplish its antibacterial effect using herbs; brand name and label composition are not enough reasons to make a switch from sodium fluoride + triclosan or sodium fluoride only containing toothpastes to these natural toothpastes ${ }^{18}$.

About toothpastes containing only sodium fluoride as antibacterial; T001 and T002 ranked $\left(4^{\text {th }}\right)$ and $\left(5^{\text {th }}\right)$ respectively. T005 ranked $\left(6^{\text {th }}\right)$ while T007 removed the least amount of teeth bacteria $\left(7^{\text {th }}\right)$ see Table 1 and 2. There was no significant effect of gender on volunteers picked $(p<0.01)$. There is a need for further research to ascertain the value of toothpaste formulations marketed in Nigerian open markets in reducing oral bacterial flora as toothpaste that efficiently reduces oral bacteria would contribute to dental health.

\section{CONCLUSION}

The results from our study show that though the toothpastes marketed in the open markets of Abuja are of good microbial quality, the toothpaste formulation efficacy in reducing oral bacteria flora is poor, for no brand of toothpaste formulation was found to remove oral bacteria flora by up to $50 \%$. Therefore, the result from our study would appear to call for added research into the possible value of toothpaste formulations marketed in the Nigerian open markets to reduce oral bacterial flora.

\section{ACKNOWLEDGEMENT}

The authors wish to thank all the volunteers that were enrolled in this study. We acknowledge the selfless support of all the technical staff and IT students at NIPRD's Microbiology Laboratory during the period of the study.

\section{REFERENCES}

1. Oxford Concise Medical Dictionary. $5^{\text {th }}$ edition, Oxford University Press. 1997.

2. Jensena JL, Barkvoll P. Clinical Implications of the Dry Mouth: Oral Mucosal Diseases. Annals of the New York Academy of Sci. 1998; 842:1, 156-162.

3. British Dental Health Foundation, FAQ, Caring for my teeth.http://www.dentalhealth.org. Acessed on 7 February 2005.

4. Collins WJ, Walsh TF. Handbook for dental hygienists. 1998; pp 272-273.

5. Yost C. "Types of Bacteria in Your Mouth." http://www.madsci.org/posts/archives/dec97/878 697508.mi.r.html. Accessed October 252005.

6. Regos J, Hitz HR. Investigations on the mode of action of triclosan, a broad-spectrum antimicrobial agent. Zentbl. Bakteriol. Parasitenkd. Infektkrankh. Hyg. Abt. 1 Orig. Reihe A 1974; 226:390-401.

7. World Health Organization. Appropriate use of fluoride for human health. 1986; Geneva.

8. Moran JM., Addy M, Newcombe RG, Marlow I. A study to assess the plaque inhibitory action of a newly formulated triclosan toothpaste. J. Clin. Periodontol. 2001; 28:86-89.

9. Cochrane review. Manual versus powered tooth brushing for oral health. The Cochrane Library, Issue 3, 2004.

10. Michell DA, Michell L .Oxford Handbook of Clinical Dentistry. Oxford University Press. 1995; pp 255.

11. Facklam H, Margery B. Bacteria Canada: Fitzhenry \& Whiteside Ltd. 1995; pp. 7-9.

12. Binney A, Addy M, Owens J, Faulkner J, McKeown $S$, Everatt L. A 3-month home use study comparing the oral hygiene and gingival health benefits of triclosan and conventional fluoride toothpastes. J. Clin. Periodontol. 1996; 23(11):; 1020-1024.

13. Owens J, Addy M, Faulkner J. An 18-week homeuse study comparing the oral hygiene and gingival health benefits of triclosan and fluoride toothpastes. J Clin Periodontol 1997; 24(9) 626631.

14. Rosin $M$, Kramer A, Detlef B, Gerrit R, Kocher $T$. The effect of a SCN/H2O2 toothpaste compared to a commercially available triclosan-containing toothpaste on oral hygiene and gingival health a 6-month home-use study. J Clin Periodontol. 2002; 29(12): 1086-1091. 


\section{Okpalugo et al}

15. De Salva SJ, Kong BM, Lin YJ. Triclosan: a safety profile. Am J Dent 1989; 2:185-196.

16. Fatima S, Farooqi AH, Kumar R, Kumar TR, Khanuja $S P$. Antibacterial activity possessed by medicinal plants used in tooth powder. J. Med. Arom. PI. Sci. 2000; 22:187-189
17. Mullally BH, James JA, Coulter WA, Linden GJ. The efficacy of herbal-based toothpaste on the control of plaque and gingivitis. J. Clin. Periodontol. 1995; 22(9):686-9

18. Natural doesn't always mean safe. Health Stress 1998; p42 